\title{
Getting Things Done by Middle Manager
}

\author{
Kaoru TsUDA ${ }^{\text {a) }}$ and Hidenori SATO ${ }^{\text {b) }}$
}

\begin{abstract}
Much research has been conducted on the role of the middle manager; however, most of the studies in research on this topic have focused on the middle manager's managerial work. However, upon surveying 2,183 managers at Japanese firms, we found that $87 \%$ of managers were actually engaged in nonmanagerial work. Furthermore, in extreme cases where middle managers responded that there was either not enough or too much non-managerial work, team performance was poor, while in cases where middle managers did an appropriate amount of nonmanagerial work, team performance was good.
\end{abstract}

Keywords: middle manager, non-managerial work, team performance

\footnotetext{
a) Recruit Career Co., Ltd.

b) Faculty of Business Sciences, University of Tsukuba, 3-29-1 Otsuka, Bunkyo-ku, Tokyo, Japan, sato.hidenori.fn@u.tsukuba.ac.jp

A version of this paper was presented at the ABAS Conference 2020 Summer (Tsuda \& Sato, 2020).

(C) 2020 Kaoru Tsuda and Hidenori Sato. This is an Open Access article distributed under the terms of the Creative Commons Attribution License, which permits unrestricted reuse, distribution, and reproduction in any medium, provided the original work is properly cited.
} 


\section{Introduction}

Middle managers play a key role in linking the top and bottom levels of an organization (Harding, Lee, \& Ford, 2014). Because of this, much research has been done on the role of the middle manager from a number of approaches. These aspects include boundary work (Azambuja \& Islam, 2019), routine creation (Yamashiro, 2019), sensemaking (Balogun \& Johnson, 2004; Rouleau \& Balogun, 2011), and strategic roles (Mantere, 2008). These studies all focused on middle managers' managerial work. ${ }^{1}$

In truth, however, some middle managers also perform the same type of non-managerial work as their team members at the same time that they do their managerial work. In this paper, "non-managerial work" refers to the general work that is usually done at the workplace by team members to enable the team to maximize its performance and achieve its goals. Managerial work and non-managerial work are considered different in nature (Mintzberg, 1973; Sheel \& Vohra, 2016), which is the reason for which some team members do not necessarily succeed as managers when they are promoted because of their non-managerial work performance (Sato, 2015).

A middle manager is a person who has been assigned subordinates within a firm and leads that team as their main performance evaluator. This paper seeks to identify the impact of non-managerial work done by middle managers by surveying middle managers at Japanese firms. The survey found that most managers actually perform both managerial work and non-managerial work; that team performance is poor in extreme cases when the amount of nonmanagerial work performed is either too little or too much; and that team performance is good when the middle manager is doing an

1 For more on managerial work, see Foster, Hassard, Morris, and Wolfram Cox (2019) and Korica, Nicolini, and Johnson (2017). 
appropriate amount of non-managerial work.

\section{Research and Data}

For our data, we used the Recruit Works Institute's Survey of Management Behavior (2019). This survey targets company managers. The actual survey, which was subcontracted to a survey company, took the form of an online questionnaire. Survey subjects were those who met all of the following criteria (a)-(c):

(a) Is a full-time employee

(b) Currently works for a company that has at least 100 employees

(c) Is currently in a managerial position that is equivalent to a section head, with the responsibility of reviewing the performance of one or more subordinates

The survey was administered in March 2019. Surveys were sent to 3,129 people, 2,183 of whom responded. Of the 2,183 respondents, $96.3 \%$ were male and $3.7 \%$ were female. In terms of age, $2.6 \%$ were in their 30 s or younger, $41.3 \%$ were in their 40 s, $52.5 \%$ were in their 50 s, and $3.6 \%$ were in their 60 s. In addition, the breakdown by sector was led by manufacturing at $32.7 \%$, followed by finance $\&$ insurance at $13.9 \%$, data communications at $11.1 \%$, and wholesale $\&$ retail at $10.0 \%$. Other sectors in all comprised less than $10 \%$ of responses, the largest of which was services at $8.4 \%$. As for job type, 35.4\% were in planning and management, $29.1 \%$ were in sales, $17.1 \%$ were in technology and research, $7.7 \%$ were in systems engineering, $5.1 \%$ were in production, and $5.6 \%$ were in other areas.

Team performance was measured as the average of the following seven items ranked on a 5-point scale.

1. Our team is judged by our boss to be working efficiently.

2. Our team is praised by our boss for performing well. 
3. Our boss says that we are a team in which young members grow.

4. The subordinates whom I have trained are promoted quickly.

5 . Our team is rated by our boss as generating stable output.

6. I am often entrusted with training new employees and midcareer recruits.

7. Our team is rated by our boss as being active in generating innovation.

\section{Results}

First, how much time do Japanese firms' middle managers actually spend on their assigned tasks in the workplace? We elicited responses to the following question:

Q: Of your total work time, about how much of it (in percentage terms) do you spend on "playing work" (work that is the same as what your subordinates do)? If you do not do any playing work, please choose, "I do not do any playing work."

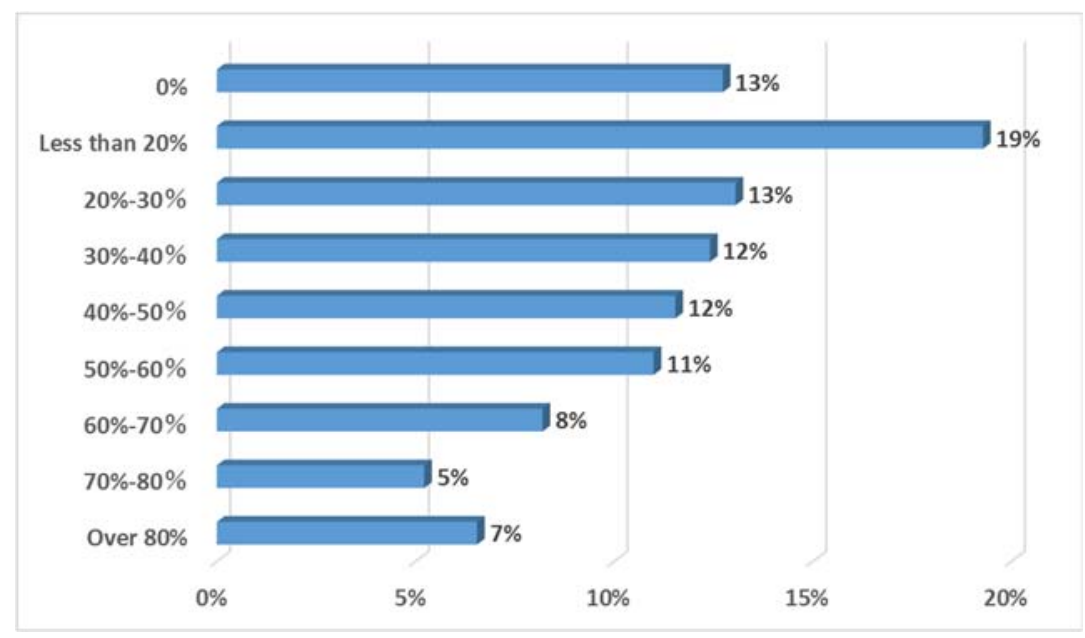

Figure 1. Proportion of non-managerial work 
The survey findings are shown in Figure 1.

Only $13 \%$ of middle managers were doing management work exclusively; $87 \%$ of middle managers were doing their assigned work in the workplace; and some of them were even spending $80 \%$ or more of their time on non-managerial work.

Next, why are middle managers spending time on non-managerial work? To find out the answer, we asked the following question. We prepared 10 choices and allowed multiple responses.

Q: Why do you perform "playing work" (work that is the same as what is performed by your subordinates)? Please mark all that apply from among the following items.

The findings are shown in Figure 2.

The most frequent answer, given by $57.3 \%$, was that the team has a lot of work to do, which means that the manager has to do both

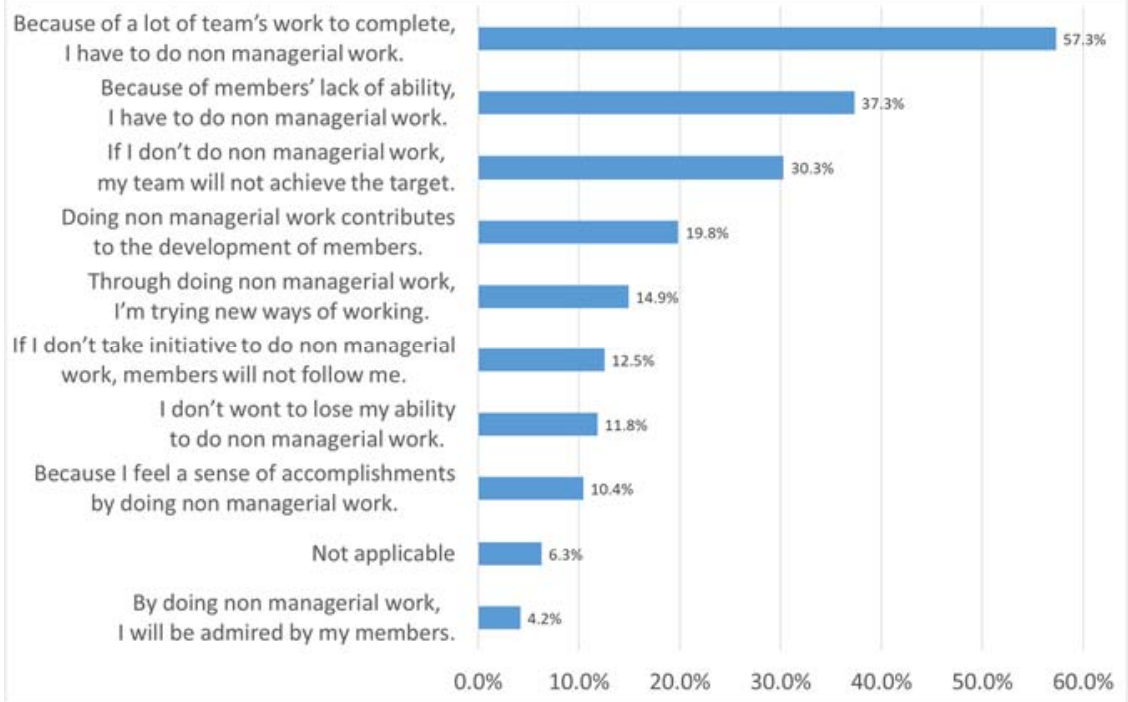

Figure 2. Reasons for non-managerial work 
managerial work and the same work as their team members. The next most frequent answer, given by $37.3 \%$ of respondents, was that the team is not big enough. This was followed by $30.3 \%$ saying that the manager has to do non-managerial work so that the team meets its performance goals. Thus, the middle managers are trying to boost their teams' performance by doing the same work that their team members do, in addition to managing them. The next most frequent responses were that doing non-managerial work contributes to the development of team members (19.8\%) and that doing nonmanagerial work allows the middle manager to try out new ways of working (14.9\%). Thus, we can surmise that in addition to helping their teams achieve their performance goals, middle managers do non-managerial work to help develop their subordinates or to try out new ways of doing the job.

Table 1 shows the relationships between the time that middle

Table 1. Non-managerial work, team performance and number of subordinates

\begin{tabular}{llllll}
\hline $\begin{array}{l}\text { Proportion of non- } \\
\text { managerial work }\end{array}$ & $N$ & \multicolumn{2}{c}{ Team performance } & \multicolumn{2}{c}{$\begin{array}{c}\text { Number of } \\
\text { subordinates }\end{array}$} \\
\hline average & $S D$ \\
\hline Less than 20\% & 278 & 3.08 & 0.53 & 12.15 & 24.68 \\
$20 \%-30 \%$ & 285 & 3.24 & 0.58 & 9.82 & 10.02 \\
$30 \%-40 \%$ & 3.27 & 0.52 & 9.65 & 12.54 \\
$40 \%-50 \%$ & 271 & 3.22 & 0.54 & 8.70 & 10.82 \\
$50 \%-60 \%$ & 252 & 3.14 & 0.52 & 7.67 & 5.71 \\
$60 \%-70 \%$ & 240 & 3.18 & 0.55 & 7.04 & 4.91 \\
$70 \%-80 \%$ & 179 & 3.01 & 0.51 & 6.70 & 4.96 \\
Over $80 \%$ & 114 & 3.09 & 0.57 & 6.46 & 4.80 \\
\hline Total & 143 & 2.86 & 0.66 & 6.14 & 7.83 \\
\hline
\end{tabular}


managers spend on non-managerial work, their teams' performance, and the size of their teams.

In addition, from Figure 3, we can see the following. First, the proportion of time that middle managers spend on non-managerial work is less when the team is large and more when the team is small. Next, looking at the relationship with team performance, we can see that overall, the more time a middle manager spends on nonmanagerial work the worse the team's performance. However, team performance does not necessarily get better when the middle manager is doing only managerial work. Team performance is best when middle managers are spending $20 \%-30 \%$ of their time on nonmanagerial work.

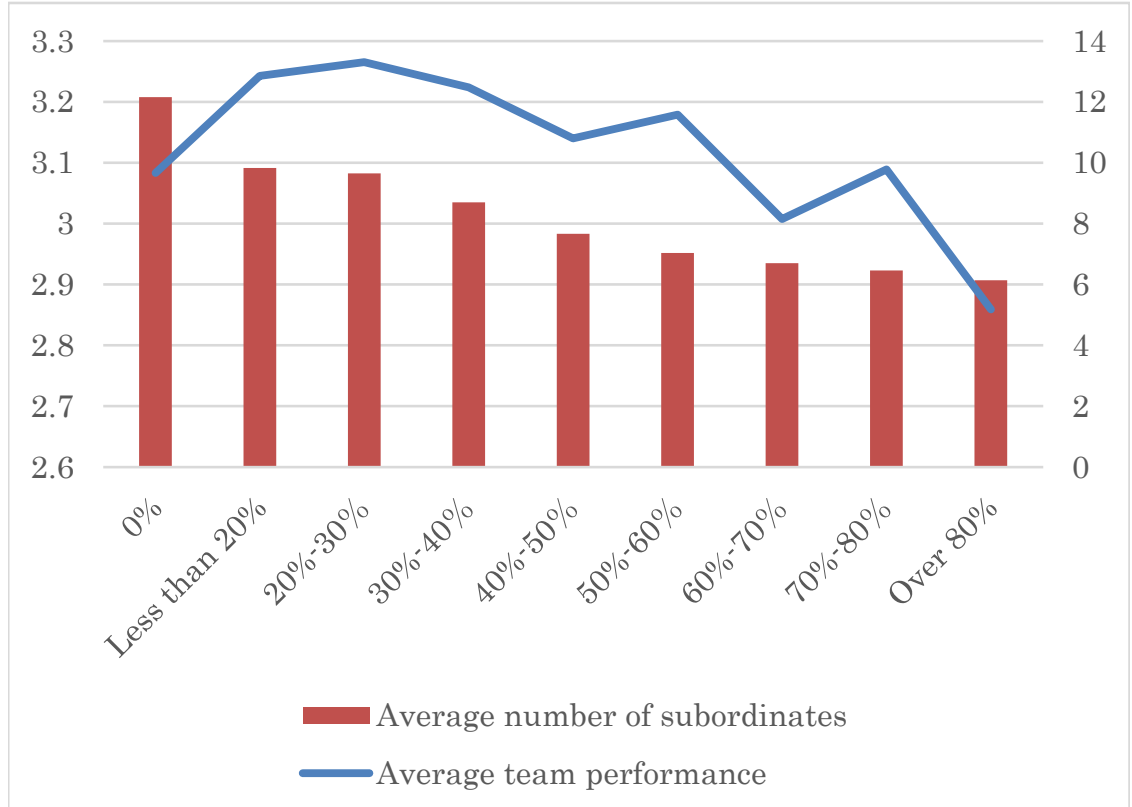

Figure 3. Average team performance and number of subordinates 


\section{Discussion}

It seems that the role of a middle manager is to improve the team's performance by managing the members of the team. However, in most Japanese firms, many middle managers do the same work that their subordinates do, in addition to their own managerial work, and in terms of team performance, middle managers who do some nonmanagerial work have better team performance than do those who do only managerial work. Why is that?

First, middle managers who only do managerial work lose the chance to refresh their knowledge and skills in the work that their subordinates are doing. For example, on the sales floor, sales staff come into direct contact with clients, while middle managers make staff assignments, monitor work progress, set departmental policies, and so forth. Even if middle managers have had experience interacting with clients, if they no longer do that, they have no opportunity to keep up with the required knowledge and experience. Even when managing their subordinates' work, they rely on their own experience. This has the effect of hampering organizational change ${ }^{2}$ and may lead to a decline in team performance (Sato, 2015).

Second, although in Figure 2, 19.8\% of respondents said that they did non-managerial work to develop their subordinates, the connection between non-managerial work done by managers and personnel development is that it constitutes an important learning opportunity for team members when they can learn by watching how their manager does the job. However, it must be noted that if it gets to the point that middle managers are doing so much non-managerial work that they are taking over team members' jobs, the team

2 See Abe (2019), Higgs and Rowland (2011), Hill, Seo, Kang, and Taylor (2012), and Kosuge and Takahashi (2016) for more on the importance of managers in organizational change. 
members will be left with the tasks that are hardest for them, thereby leaving them with no opportunity to learn from experience.

However, the survey findings expose some problems at Japanese firms. As the reason given for doing non-managerial work by $57.3 \%$ of respondents in Figure 2, when there are fewer team members than required to handle the volume of work, middle managers have to spend more time doing non-managerial work, and this tendency seems to be stronger at workplaces that impose short-term work quotas. Hence, the truth is that there is so much work that the middle manager is not spending enough time on managerial work. In particular, as shown in Figure 3, the tendency is that the larger the proportion of non-managerial work the smaller the team. This indicates the possibility that the organization was already mired in problems with human resources allocation before the middle manager decided to act. For example, if middle managers cannot spend enough time on managerial work, they lose the chance to improve their own management skills by building experience as middle managers, and this has a negative impact on the firm over the long term.

\section{Acknowledgments}

This work was supported by JSPS Grant-in-Aid for Publication of Scientific Research Results, Grant Number JP16HP2004.

The authors deeply appreciate the cooperation of Recruit Works Institute.

\section{References}

Abe, M. (2019). Leader's episodic change and followers' continuous change: The case of Rakuwakai Otowa Hospital. Annals of Business Administrative Science, 18, 1-12. doi: 10.7880/abas.0181206a 
Azambuja, R., \& Islam, G. (2019). Working at the boundaries: Middle managerial work as a source of emancipation and alienation. Human Relations, 72(3), 534-564.

Balogun, J., \& Johnson, G. (2004). Organizational restructuring and middle manager sensemaking. Academy of Management Journal, 47(4), 523-549.

Foster, W. M., Hassard, J. S., Morris, J., \& Wolfram Cox, J. (2019). The changing nature of managerial work: The effects of corporate restructuring on management jobs and careers. Human Relations, 72(3), 473-504.

Harding, N., Lee, H., \& Ford, J. (2014). Who is "the middle manager"? Human Relations, 67(10), 1213-1237.

Higgs, M., \& Rowland, D. (2011). What does it take to implement change successfully? A study of the behaviors of successful change leaders. Journal of Applied Behavioral Science, 47(3), 309-335.

Hill, N. S., Seo, M.-G., Kang, J. H., \& Taylor, M. S. (2012). Building employee commitment to change across organizational levels: The influence of hierarchical distance and direct managers' transformational leadership. Organization Science, 23(3), 758-777.

Korica, M., Nicolini, D., \& Johnson, B. (2017). In search of "managerial work": Past, present and future of an analytical category. International Journal of Management Reviews, 19(2), 151-174.

Kosuge, R., \& Takahashi, N. (2016). The survival of market orientation through artificial selection. Annals of Business Administrative Science, 15, 273-284. doi: 10.7880/abas.0161109b

Mantere, S. (2008). Role expectations and middle manager strategic agency. Journal of Management Studies, 45(2), 294-316.

Mintzberg, H. (1973). The nature of managerial work. New York, NY: Harper \& Row.

Rouleau, L., \& Balogun, J. (2011). Middle managers, strategic sensemaking, and discursive competence. Journal of Management Studies, 48(5), 953-983.

Sato, H. (2015). Organizational change and temporal myopia. Annals of Business Administrative Science, 14, 323-333. doi: 10.7880/abas. 14.323 
Sheel, R. C., \& Vohra, N. (2016). Relationship between perceptions of corporate social responsibility and organizational cynicism: The role of employee volunteering. International Journal of Human Resource Management, 27(13), 1373-1392.

Tsuda, K., \& Sato, H. (2020, July). Getting things done by middle manager. Paper presented at ABAS Conference 2020 Summer, University of Tokyo, Japan.

Yamashiro, Y. (2019). Disincentives of organizational routines transfer: Case of adaptive radiation in a sales and marketing company. Annals of Business Administrative Science, 18, 37-49. doi: 10.7880/abas.0190303a 